\title{
STRATEGIC PRIORITIES FOR THE INTERNAL MIGRATION PROCESSES REGULATION IN UKRAINE
}

\author{
Olga Balueva', Elena Chuprina ${ }^{2}$ \\ Donetsk State University of Management (Mariupol), Ukraine
}

\begin{abstract}
As the result of the annexation of the Crimea and Donbass military conflict, there was an emergence of forced migration. It ought to be emphasized that today issues related to addressing problems of internally displaced persons (IDPs), are relevant and require an integrated approach. The increase in the number of IDPs in the country raises the issue of identifying the strategic priorities of the state policy. The purpose of this research is to formulate strategic priorities of the state policy of support for IDPs.' The subject of the study is theoretical and methodological principles of the state policy to support IDPs. The research methodology includes a set of scientific research methods that provide identifying the strategic priorities of the state policy for IDPs' support, developing effective mechanisms for these priorities achievement, and conceptual vision of solving IDPs' problems. In the course of investigations, the following methods are used: analysis while studying the main problems of internally displaced persons; logical synthesis and synthesis while drawing conclusions. Results. Scientific novelty of the article. In the article, the conceptual foundations of the IDPs support have been formed, an attention has been focused on the feasibility of using a strategic approach, which involves the formation and implementation of a set of strategically oriented measures aimed at solving the most acute issues and matters related to internal forced migration, directing the IDPs potential and internally displaced businesses to strengthen local communities and social and economic development of the resettlement territories. The main stages and conceptual foundations for the Strategy formation on the IDPs support have been proposed. The strategy is based on an integrated approach to addressing IDPs and internally displaced businesses, taking into account the interests of host communities. Practical implications. The result of the Strategy implementation ought to be approved by the strategic migration model for Ukraine's internal migration aimed at promoting the implementation of the basic IDPs and internally displaced businesses rights; ensuring the social and economic integration of the IDPs into the host society; promotion of country territories' social and economic development; reducing the level of social and psychological tension in host communities; creating new jobs; improvement of the investment climate; increasing the efficiency of using the country intellectual potential and its human resources. Value / originality. Solving the urgent issues associated with forced displacement processes, including integration and adaptation to host communities.
\end{abstract}

Key words: strategic priorities, government policy, internally displaced persons, support strategy, strategic management.

JEL Classification: H11, J68, R23, 015

\section{Introduction}

As the result of the annexation of the Crimea and Donbass military conflict, there was an emergence of forced migration. It ought to be noted that the category of internally displaced persons (IDPs), who were forced to leave their place of residence due to the war, was first recorded in Ukraine in 2014, forming a new type of migration for Ukrainian population.

As of the end of 2017, 1.5 million citizens were forced to leave their places of residence and sought refuge in other parts of the country, which led to the redistribution of population between the territories (Official site of the Ministry of Social Policy of Ukraine, 2018).

The increase in the number of IDPs in Ukraine requires the formation and implementation of a modern, integrated, balanced state policy aimed at solving the issues associated with internal forced migration, including the adoption of long-term solutions that can create effective national instruments of public administration for overcoming the negative

\footnotetext{
Corresponding author:

${ }^{1}$ Donetsk State University of Management (Mariupol)

E-mail: balueva@ukr.net

${ }^{2}$ Department of Marketing, Donetsk State University of Management (Mariupol)

E-mail: eochuprina@ukr.net
} 
consequences for both the IDPs and host communities, the integration of IDPs into the life of the host society in the areas of displacement for further comfort living, realizing the IDPs' potential on a new place and strengthening local communities.

The issues of IDPs' difficulties are studied by such scholars as O. Balakireva (Balakireva, 2014), T. Doroniuk, A. Solodko (Doroniuk \& Solodko, 2015), E. Libanova (Libanova, 2014), O. Malinovskaya (Malinovskaya, 2015), and others.

The problem of IDPs' integration and adaptation in Ukraine is very relevant and contains a significant number of unresolved issues that require active research.

Within this framework, the issue of identifying the strategic priorities of the state policy for IDPs' support, developing effective mechanisms for these priorities achievement and conceptual vision for IDPs' matters solving have been actualized.

The purpose of the article is to formulate strategic priorities of the state policy of support for IDPs.

\section{Strategic component}

\section{of internally displaced persons' support}

The results of the research allowed stating that the undeniable positive feature of the current social development in Ukraine is to raise the attention of politicians, scientists, and ordinary citizens to the issues of strategic priorities formation and achievement, strategic principles for management enhancement in various spheres of the economy and public administration development.

Strategic management in the field of IDP support, aimed at a long-term perspective, creates favourable conditions for the further development of civil society in Ukraine, the introduction of an effective mechanism for the interaction of its institutions with the executive and local self-government bodies on the basis of partnership and mutual responsibility, ensuring the implementation and protection of rights and human freedoms, and is aimed at involving IDPs into the economic, social, cultural, and political spheres of life in host communities.

It ought to be emphasized that the readiness for the development and adoption of a state policy on internal displacement is an essential indicator for the recognition by the national authorities of the relocation and related responsibilities issues, and of the fact that they regard this issue as a national priority. UN resolutions encourage state governments that are faced with relocations within the country to take government programs aimed at IDPs protecting and assisting.

It is necessary to pay attention to the fact that in management theory, there is an integration of strategy and corresponding mechanisms, which mutually determine each other.

It should be noted that the effective state policy implementation concerning IDPs is appropriate on the basis of the organizational and economic mechanism formation for ensuring strategic management in this area. It represents a set of organizational and economic methods and tools that, based on legal norms, allow the state and local governments to provide support for IDPs, taking into account the interests of host communities.

The structure of the organizational and economic mechanism for providing strategic management in the IDPs' support direction is presented in Fig. 1.

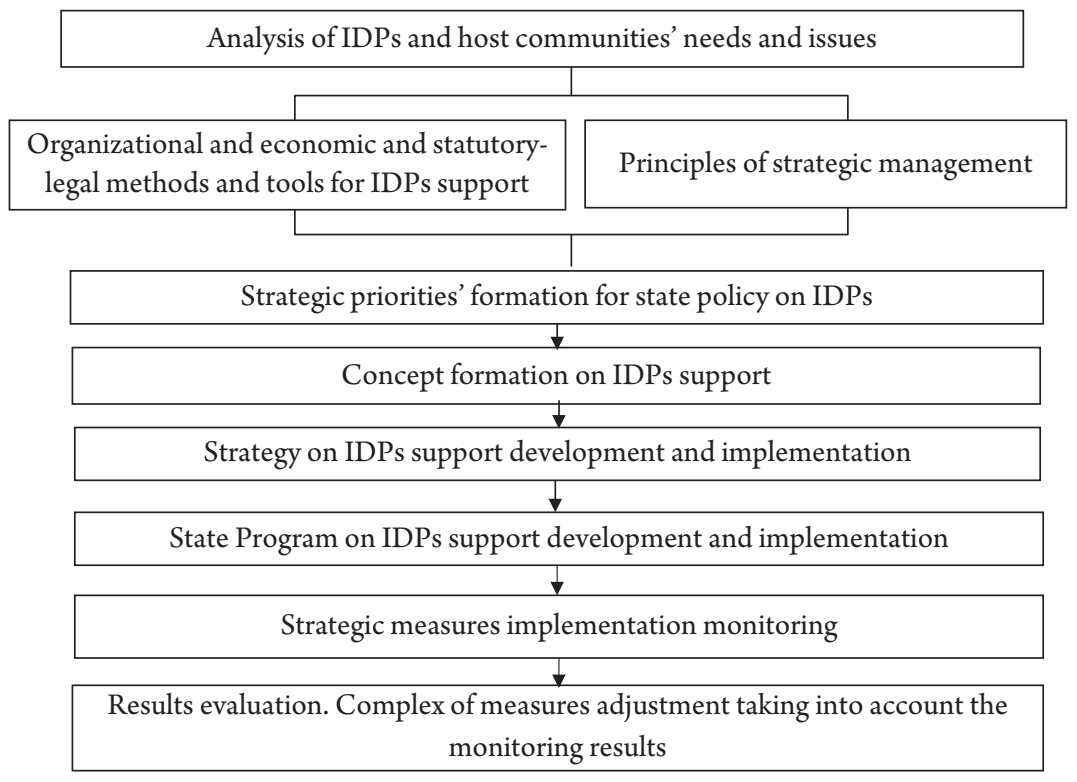

Fig. 1. The organizational and economic mechanism structure for providing strategic management on IDPs support

Source: developed by the authors 
It ought to be noted that the organizational and economic mechanism for providing strategic management on IDPs support is a complex and consists of separate elements: financial mechanism, institutional mechanism, investments attraction, a public-private partnership, state regulation and support mechanism. This complexity enhances its effectiveness.

The authors of the article emphasize that the lack of a strategic component in the modern management of internal forced migration leads to an increase in the social isolation of citizens, increases the vulnerability to various forms of their rights violation.

\section{Strategic priorities for internally displaced persons' support}

It should be emphasized that the strategic priorities of the state policy on IDPs are the most important directions aimed at solving the issues of this category of citizens and host communities connected with internal forced migration, which carry out a number of particular actions that the state or an authorized subject of management should take for the realization and protection of the IDPs rights, taking into account the interests of host communities in the short and long terms.

The priorities of the state policy in this area are determined on the basis of the IDPs and host communities' needs and priorities analysis, which in turn allow clearly defining the goals and strategy for their achievement.

In the methodological framework, when substantiating priorities, the following principles need to be taken into account:

- the democracy principle means the activities openness to form a policy on IDPs support, the involvement of the scientific community and society in its development;

- the adaptability principle is realized through the policy on IDPs support formation taking into account possible changes in the external environment, which may result in the strategic objectives correction, priority measures for the IDPs protection and support, as well as mechanisms for its implementation;

- the purposefulness principle determines the directions of the state policy on IDPs support in order to achieve the common goal of all actors;

- the balance principle is manifested in the balance of interests of all subjects of state policy, displaced persons and population in the territories of displacement in relation to strategic goals and priorities; the balance of economic, social, and other goals; balancing the use of the resource base necessary to the goals' accomplishment;

- the humanism principle expresses a system of views that determine the value of man as a person, his/her right to freedom, happiness, development, the identification of his/her abilities, which considers the benefit of a person as that for assessing social institutions;

- the synergy principle is synchronization of the major reforms implemented in the country and affect the formation of national tools on IDPs support and, at the same time, the coordination of the municipalities support directions in regional development;

- the subsidiarity principle involves the decentralization of power and the competence accomplishment in order to protect and support IDPs at the level of governance where they can be implemented more effectively. Interaction of public authorities and local self-government with civil society institutes;

- the conceptual approach to IDPs support and protection principle should be based on the adoption of a basic document that would lay the main directions on IDPs state policy, aimed at formulating a concept of their support, socio-economic and psychological adaptation, integration into the host society, that would be followed both by government and private structures while choosing their further activities.

It cannot be but mentioned that the strategic priorities of the state policy concerning IDPs are the basis for the IDPs support Concept formation, as well as the relevant State Program.

According to the results of the research, IDPs face certain problems and obstacles when moving to the new place that affects the level of integration into host communities and often hinder the adaptation processes. Among the main ones, the following should be noted: the employment; housing; material issues caused by difficulties with the employment and housing, loss of property and the need to adapt into a new city; cases of discrimination because of IDP status, the existence of legal and administrative barriers that impede their rights realization.

Generally, it ought to be noted that forced displacement of citizens is associated with a number of challenges for many local communities, which are manifested in the growing burden on local labour markets, the issues of placement, employment, medical care, access to education, cultural and social reintegration, and can also become the cause of a social conflict.

The authors emphasize that the crucial factor for the IDPs integration and stability is solving problems (for example, employment) for both the IDPs and local residents within the territorial community. Therefore, the issues of integration and cooperation of local residents and IDPs, confidence building, mutual respect and partnership relations, that is, social cohesion enhancement of the population, are urgent.

Speaking about the problems associated with forced internal migration, one should pay attention to the difficulties faced by the displaced business as a result of hostilities. According to the results of the conducted research, among the main ones, the following can be noted: the difficulties associated with the evacuation 
of capital equipment and property; limited access to financial and credit resources, difficulties in obtaining a loan; unfavourable regulatory policy; complication with the enterprise or an individual entrepreneurship registration.

In general, the internally displaced business has some potential to partially solve the issue of additional jobs creation (including for IDPs), and the local communities' development.

Addressing the acute issues encountered by IDPs, internally displaced businesses and local residents within the territorial community requires systematizing the strategic priorities of the relevant state policy with the further development of applied mechanisms for their achievement.

Consequently, the formation of the main strategic priorities of the state policy regarding the IDPs ought to be directed in two ways: IDPs and internally displaced businesses encouragement; host communities support for the effective resolution of IDPs problems. Within the framework of these strategic priorities, it seems advisable to develop measures that can ensure the realization of the IDPs' basic rights.

\section{IDPs Support strategy}

It ought to be noted that in the generally accepted context, the management strategy, aimed at supporting the IDPs, is a system of conceptual provisions on the most effective directions of the migration policy development in the field of internal forced migration, solving the urgent issues associated with forced displacement processes, including integration and adaptation to host communities.

Strategy development is carried out stepwise, each of which is in its own way important, and therefore requires the creation of prerequisites for its successful implementation.

The formation process of the IDPs Support Strategy consists of successive steps, namely:

- definition of the purpose and the main tasks, the realization of which will allow achieving the strategy;

- definition of criteria and factors of influence on the strategy formation and implementation process;

- definition of the tool, which provides the strategy main provisions implementation;

- definition of the resource base: financial, information support;

- substantiation of a group of acceptable generalized alternatives, their analysis, determination of the predicted environment condition;

- the choice of the most acceptable alternative;

- substantiation of standards and evaluation criteria, for which the analysis of results is planned;

- analysis of the achievement degree of the obtained results and their comparison with the planned ones.
The authors emphasize that this strategy should be integrated with existing national strategies and programs aimed at IDPs support.

Using the positive world experience, a set of issues related to forced domestic migration in the country and established strategic priorities for the IDPs support, the main criteria to be met by the IDP Support Strategy ought to be formulated (Table 1).

Table 1

\section{The main criteria to be met} by the IDP Support Strategy

\begin{tabular}{|c|c|}
\hline Criteria & Criterion characteristic \\
\hline $\begin{array}{l}\text { Systemic } \\
\text { influence on } \\
\text { the national } \\
\text { economic } \\
\text { development }\end{array}$ & $\begin{array}{l}\text { Raising the national economic } \\
\text { competitiveness level, stimulating economic } \\
\text { growth, the existence of a significant } \\
\text { inter-sectoral multiplier, contributing to } \\
\text { strengthening macroeconomic stability }\end{array}$ \\
\hline Efficiency & $\begin{array}{l}\text { Long-term implementation and duration of } \\
\text { the achieved effect }\end{array}$ \\
\hline Social orientation & $\begin{array}{l}\text { Tangible results of the project in order to } \\
\text { improve the quality of citizens' life }\end{array}$ \\
\hline $\begin{array}{l}\text { Focus on the } \\
\text { economic, social, } \\
\text { legal systems } \\
\text { modernization }\end{array}$ & $\begin{array}{l}\text { Achieve the Strategy goals through the } \\
\text { reforms in these areas implementation }\end{array}$ \\
\hline $\begin{array}{l}\text { Use of national } \\
\text { resource }\end{array}$ & $\begin{array}{l}\text { Strategy orientation to strengthening } \\
\text { national economic independence, decreasing } \\
\text { dependence on fluctuations of the world } \\
\text { economic situation }\end{array}$ \\
\hline Integration & $\begin{array}{l}\text { Integration possibility within the framework } \\
\text { of the Strategy implementation with the state } \\
\text { and business efforts }\end{array}$ \\
\hline $\begin{array}{l}\text { Promotion } \\
\text { of territorial } \\
\text { development }\end{array}$ & $\begin{array}{l}\text { Impact of the Strategy on the economic and } \\
\text { social situation in the regions of Ukraine, the } \\
\text { attraction of regional economic potential, } \\
\text { development of interregional cooperation. }\end{array}$ \\
\hline
\end{tabular}

Source: developed by the authors

The IDPs support strategy provides a systematic solution to the IDPs and host communities' issues associated with the internal displacement of citizens and businesses, the promotion of social and economic integration and the IDPs adaptation and the realization of their potential in a new place for the resettlement areas development and local communities strengthening in order to overcome the negative consequences associated with these processes, the growth of country social and economic potential and the national economy development.

Within the general objectives of the IDPs Support Strategy, the following should be singled out:

- forming a common understanding of the changes taking place in migration policy, in particular, in the field of internal forced migration, and a united position on this issue; definition of the state policy directions in this sphere, and the influence of the internal forced migration processes on the resettlement territories development and the national economy as a whole; 
- clarification in the course of discussions and information exchange of the most likely state, public, and private organizations actions in the field of IDPs support;

- the creation of a framework for the joint work of local communities, non-governmental organizations and enterprises in the field of IDPs support, aimed at strengthening the country's economic and demographic potential;

- assistance to economic policy subjects in making their specific decisions, which allow increasing the focus and coordination of actions aimed at IDPs support.

- It ought to be emphasized that the IDPs conceptual Support Strategy provides:
- the realization of the basic rights of IDPs and citizens according to the Constitution and in accordance with the international law principles;

- the implementation of a systematic approach that will ensure the maximum use of synergistic effects due to the presence of combined results, interdependent goals in the implementation of Strategy individual system components;

- realization of economic, investment potential of internally displaced business and resettlement areas (Fig. 2).

The strategy is based on an integrated approach to address IDPs and internally displaced businesses, taking into account the interests of host communities. Its formation and realization should be carried out

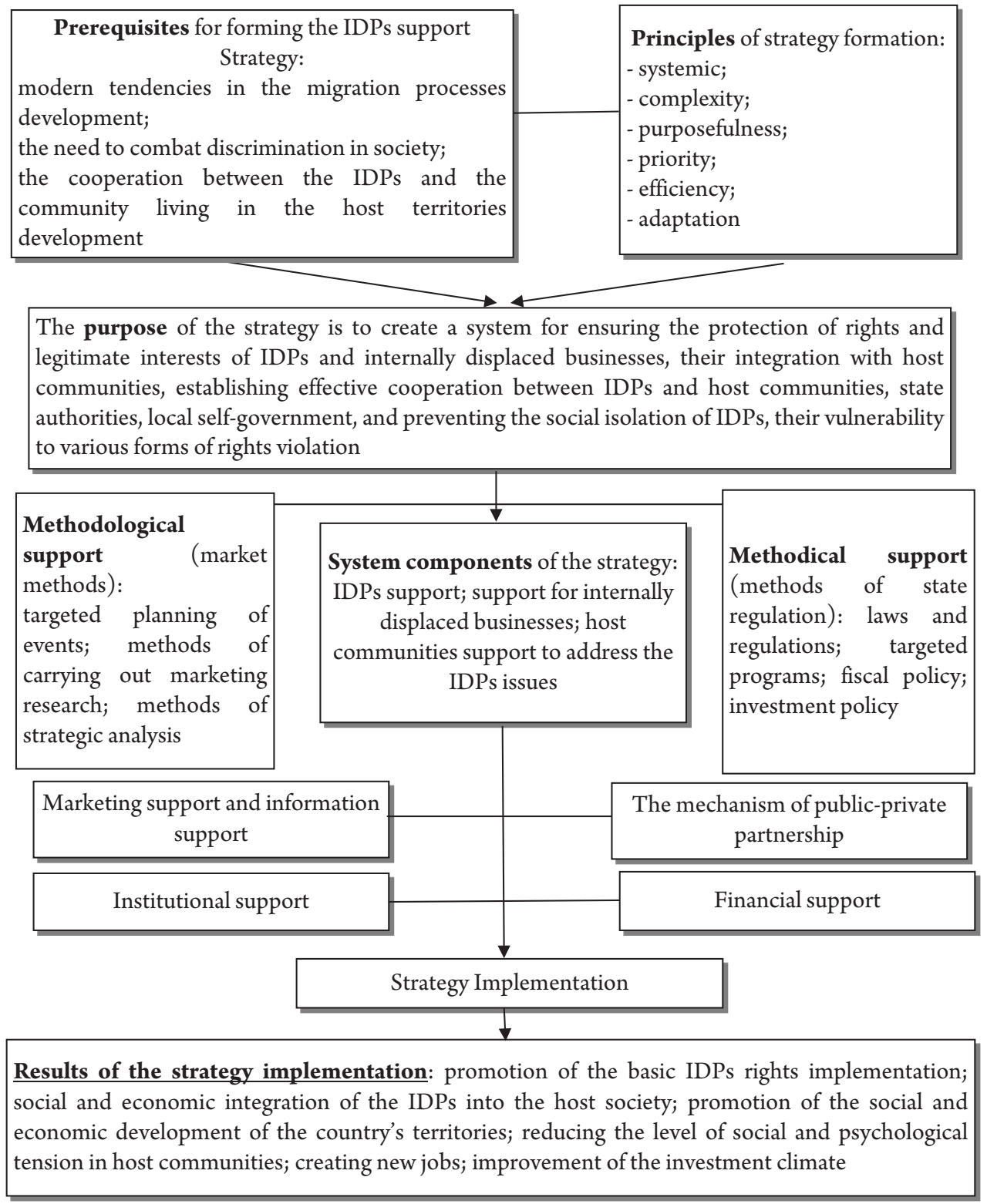

Fig. 2. The conceptual basis for the IDP Support Strategy formation

Source: developed by the authors 
according to certain system components, in compliance with which the complex measures are formed.

It should be noted that the prerogative of management in the field of migration, including domestic one, is carried out by the government. However, it ought to be combined with a partnership involving a wide range of other actors. At the general level, taking into account the specifics of domestic forced displacement, this includes the IDPs and social partners: employers, trade unions, IDPs associations, public organizations, international organizations and foundations.

The effectiveness of the Strategy is determined by the goals achievement, namely:

- creation of conditions for the IDPs basic rights realization, which will overcome the negative consequences associated with the internal forced migration processes, to avoid social isolation of IDPs;

- creation of conditions for the social and economic integration of the IDPs into the host society through the full involvement of this category of citizens in the economic, social, cultural, and political spheres of the host communities; increasing their capacity at the local level, raising awareness of how to solve social and economic issues within host communities;

- promotion of the social and economic development of the country's territories due to the realization of the IDPs' potential and internally moved the business in a new place (taking into account regional peculiarities) and strengthening of local communities;

- reducing the level of social and psychological stress in host communities, building effective communicative interaction between IDPs and the local population, involving the IDPs in the local community life, thus avoiding conflict situations between IDPs and local residents;

- creating new jobs that will help reduce social tensions and unemployment;

- improving the investment climate and attracting foreign and domestic investors in order to implement housing construction projects.

The main areas of practical implementation of the Strategy (based on the identified systemic components) are the following:

1. IDPs support: presupposes a solution to a set of tasks, the main of which are the following:

1.1. Realization of the right to work. This requires:

- the introduction of a programmatic approach to the comprehensive problem-solving of the IDPs' issues, the formation and implementation of a State Program aimed at IDPs protection and support, increasing the possibilities of IDPs employment, including through the implementation of joint projects with international organizations;

- introduction of tax incentives for employers and enterprises that have hired IDPs;

- creating opportunities for self-employment, retraining, advanced training. Enhancing employment opportunities for IDPs and their adaptation to the regional labour market by reducing their retraining time in compliance with specific employers' needs, direct internships at enterprises, institutions and organizations, individual and distance learning, and recognizing the results of non-formal vocational training;

- informing theIDPs about employmentopportunities, available employment support programs, trainings, round tables, grants to open their own business;

- disseminating information and working out the experience of the National Business Cooperation Platform, which aims to promote networking and cooperation between IDPs and members of local communities - entrepreneurs from different fields - in order to build a business, create new jobs and, in the long run, improve the business environment in Ukraine.

1.2. Realization of the right to housing. This requires: the creation of a reserve fund of housing (in communal property), to provide temporary accommodation for the most vulnerable categories of IDPs;

- introducing a system of preferential taxation for landlords who provide accommodation to IDPs, which enables them to enter into lease contracts and issue subsidies and encourage tax payments in accordance with current legislation;

- elaboration and implementation of the state mortgage lending program for the housing purchase on the primary or secondary market for a long time, the formation of the financial and legal mechanism of IDPs preferential crediting (with the mechanism elaboration for obtaining compensation for lost housing in the occupied territories);

- development and implementation of a state program aimed at the construction or purchase the affordable housing for IDPs with partial compensation of the construction (purchase) cost by the state (as an instrument of state housing policy, which implements the mechanisms of state support to IDPs, it is expedient to consider the potential of the State Fund for Youth Housing Assistance);

- consideration of the possibility to cooperate with non-governmental donor and investment organizations in the field of international housing projects implementation.

- elaboration of an organizational and legal mechanism for the losses and compensation assessment of lost housing and IDPs property as a result of hostilities and temporary occupation of the territory of Ukraine.

1.3. Overcoming the legal and administrative barriers that hinder the realization of the IDPs' rights, impede access to livelihood facilities. This requires:

- development of measures set (including using marketing potential) aimed at effective communication interaction between IDPs and state authorities. Improving the quality and accessibility of public services, as well as services working with the population; 
- maximum simplification of the procedure for obtaining administrative services for IDPs (for example, registration of property rights, liquidation of legal entities, obtaining the necessary documents, etc.);

- creation of effective information and legal support of the internal forced migration process, objective, correct coverage of its main tendencies in order to form a positive image of the IDPs in society;

- preparation, publication, and dissemination of information materials for migrants on their rights in education, social welfare, and health. Informing the IDPs regarding their rights, opportunities for realizing these rights, sources and resources for assistance receiving;

- formation and implementation of an effective system for the dissemination of information on IDPs by state authorities, expression of the position as for the interaction;

- use of libraries, social institutions, trust phones, etc. in order to inform and counsel the IDPs;

- provision of tax, levy, and other payments to enterprises and organizations involved in sponsoring, sponsorship, charity activities aimed at IDPs support; - simplification of the procedure for pension issuing, proof of the right to pension payment;

- creating the state support of the educational online platforms work for obtaining Ukrainian education for children from the temporarily occupied territory or from separate districts of Donetsk and Luhansk regions;

- development and implementation of teacher training programs for participation in distance education. Workout the mechanism of material stimulation of teachers in connection with additional workload related to working with students on an online platform;

- taking into account the actual amount of IDPs when distributing a medical subvention to the relevant local budgets;

- assistance from the Ministry of Education and Science to obtain licensing by the relevant educational institutions for conducting educational activities for the most demanded by labour market professions and specialties in order to conduct the professional training for IDPs;

- formation of an organizational and legal mechanism aimed at solving the IDPs discrimination issues in the banking sphere over the inability to independently choose a banking institution for servicing card accounts (pensions, social payments) and fully use the Savings Bank cards;

- encouraging banking institutions to provide loans when opening their own business.

2. Support for internally displaced businesses. A solution to a set of tasks is foreseen, the main of which are the following:
- implementation of a programmatic approach to the integrated problem solving of internally displaced businesses, the formation and implementation of a State program aimed at its protection and support;

- introduction of mechanisms for the opening and support the IDPs' business;

- introduction of preferential financial and credit mechanisms for supporting small and medium-sized businesses that will promote the social and economic development of host communities;

- development of a unified national base of production (commercial) areas and real estate by regions, which has to contain information on the availability of specialized premises by activity type, operational capacity, equipment, and an initial assessment of the retrofitting and commissioning costs;

- formation and implementation of the organizational and economic mechanism of the displaced business support in rural areas and peripheral districts;

- development of start-ups and youth entrepreneurial initiatives;

- promotion of local authorities on sales distribution of entrepreneurs and enterprises products made by IDPs (implementation of projects for holding exhibitions and fairs to promote products, information support for such projects).

3. Host communities support in addressing IDPs issues. For this purpose, it is expedient to implement the following set of measures:

- studying the IDPs and local communities issues and needs in the areas of resettlement;

- providing local budgets of host communities with appropriate support from the state budget, taking into account the actual number and needs of IDPs living in these communities;

- formation of a positive image of the IDPs, building the mutual understanding between the inhabitants of the host communities and the IDPs;

- highlighting issues faced by IDPs, focusing on the common problems of settlers and residents of host communities;

- support the social dialogue in communities with the participation of host communities, IDPs, public associations;

- communicative interaction between the IDPs and the local population, the involvement of the IDPs in the local community life; encouraging IDPs to participate in community life, using the IDPs' potential for community development by informing about opportunities for cooperation and partnership with civil society institutions, local authorities and host communities, community participation, public hearings, etc.;

- creation of a platform for public organizations, state bodies, etc., which deal with the IDPs issues for the systematization of their activities, development of joint projects; 
- realization of projects on the social cohesion of the population: holding concerts, festivals, exhibitions, master classes, clubs of interests, sports events, seminars, round tables, environmental initiatives, etc.

- formation and implementation of an effective communication system for the information exchange between the IDPs, community, and executive authorities;

- attracting international assistance for the social and economic development of local communities and increasing their ability to respond to the need to address the IDPs' urgent problems;

- community support in expanded networks of educational establishments, taking into account the IDPs' needs, moved to such communities, and the existing needs of local inhabitants.

The experience of foreign countries shows that to resolve IDPs' issues, a special legislative base, administrative bodies for its implementation, coordination of the efforts of various departments, as well as proper financing from the state budget are necessary. Given the limited resources available in conflict situations, international organizations can be of great help, and cooperation with them should take place within the framework of the policy of IDPs protection.

The source of resources for the Strategy implementation should be the combination of budget funds and the targeted financial and technical assistance provided by Ukraine to international organizations and foreign countries, as well as attracting funds from private domestic and foreign investors.

It should be noted that the Strategy is proposed based on models of public-private partnership. It is proposed to use the following forms and models: joint activities (in parts of the Strategy for the construction of infrastructure objects); leasing (in parts of the support Strategy of IDPs); a contract (public order) for the construction of social infrastructure, housing, etc.

It is necessary to emphasize the need for widespread dissemination of information about strategic and practical decisions taken within the framework of the Strategy, provided with appropriate informational support of strategic measures integrated with marketing. Taking this into account, it seems advisable to form a marketing program aimed at creating conditions for the full involvement of the host societies in the economic, social, cultural, and political life of the host communities, and is based on the analysis of the IDPs' matters and the obstacles that affect the integration level into host communities and hinder adaptation processes; attracting public attention to them; studying and analysing public opinion on IDPs, forming effective communication channels with target groups.

In the process of changing the social and economic, political situation in the country and taking into account the effectiveness of the measures implemented, the adjustments are to be made into the developed Strategy (in particular, regarding its goals or implementation mechanisms), aimed at eliminating new challenges and maximizing the use of available opportunities.

It is worth to be underlined that the Strategy should become a fundamental document when developing and implementing programs on specific systems of IDPs and internally displaced businesses support and country social and economic development.

\section{Conclusions}

The increase in the number of IDPs in the country raises the issue of identifying the strategic priorities of the state policy on IDPs. It is advisable to target their formation in two directions: IDPs and internally displaced businesses support, and host communities support for the effective resolution of IDPs matters.

The strategic priorities of the state policy on IDPs are the basis for strategy further development, an action plan for the state, regional, and other programs.

In the article, the conceptual foundations of the IDPs support have been formed, attention has been focused on the feasibility of using a strategic approach, which involves the formation and implementation of a set of strategically oriented measures aimed at solving the most acute issues and matters related to internal forced migration, directing the IDPs potential and internally displaced businesses to strengthen local communities and social and economic development of the resettlement territories.

The main stages and conceptual foundations for the Strategy formation on the IDPs support have been proposed. The strategy is based on an integrated approach to addressing IDPs and internally displaced businesses, taking into account the interests of host communities.

The result of the Strategy implementation ought to be the approved by the strategic migration model for Ukraine's internal migration aimed at promoting the implementation of the basic IDPs and internally displaced businesses rights; ensuring the social and economic integration of the IDPs into the host society; promotion of country territories' social and economic development; reducing the level of social and psychological tension in host communities; creating new jobs; improvement of the investment climate; increasing the efficiency of using the country intellectual potential and its human resources. 


\section{References:}

Balakireva, O. (2014) Spektr problem vymushenykh pereselentsiv v Ukrayini: shvydka otsinka sytuatsiyi ta potreb [Range of problems of internally displaced persons in Ukraine: quick assessment of the situation and needs]. Proceedings of the Vymusheni pereselentsi $v$ Ukrayini: pytannya terminovoho ta serednostrokovoho reahuvannya: materialy kruhloho stolu (Ukraine, Kyiv, July 9, 2014). Retrieved from: http:// www.uisr.org.ua/news/36/83.html (accessed 21 November 2017).

Doronyuk, T., Solodko, A. (2015) Vyroblennia polityky shchodo vnutrishno peremishchenykh osib v Ukraini: zvit [Developing a policy for internally displaced persons in Ukraine: report]. Retrieved from: http://www.diversipedia. org.ua /sites/default/files/sedos_policy_idps.pdf. (accessed 25 November 2017).

Libanova, E. (2014) Vymushene pereselennya z Donbasu: masshtaby ta vyklyky dlya Ukrayiny (za materialamy naukovoyi dopovidi na zasidanni Prezydiyi NAN Ukrayiny 8 zhovtnya 2014) [Forced displacement from Donbass: scale and challenges for Ukraine (information from scientific report at the meeting of Presidium of NAS of Ukraine October 8, 2014)]. Visnyk NAN Ukrayiny, no. 12, pp. 15-24.

Malynovska, O. (2015) Vnutrishnya mihratsiya ta tymchasovi peremishchennya $v$ Ukrayini v umovakh politychnykh ta sotsialno-ekonomichnykh zahroz [Internal migration and temporary movement in Ukraine in terms of political, social and economic threats]. Kyiv: Natsionalnyy instytut stratehichnykh doslidzhen pry Prezydentovi Ukrayiny. Retrieved from: http://www.niss.gov.ua/content/articles/files/vnutrishnya_migratsia-45aal.pdf. (in Ukrainian) (accessed 21 November 2017).

Ofitsiynyy sayt Ministerstva sotsialnoi polityky Ukraiyny (2018) [Official site of the Ministry of Social Policy of Ukraine]. Retrieved from: http://www.mlsp.gov. ua/labour/control/uk/publish/article?art_id=190239\&cat_ id=107177 (accessed 15 January 2018). 